\title{
Isolation and characterization of cellulolytic bacteria, Bacillus sp. EFL1, EFL2, and EFP3 from the mixed forest
}

\author{
Hwa Rang Park ${ }^{1,2} \cdot$ Ki-Cheol $\mathrm{Oh}^{3} \cdot$ Bong-Gyu Kim ${ }^{1}$

\section{혼효림으로부터 셀룰로오스분해 박테리아 분리 및 효소학적 특성규명}

박화랑 ${ }^{1,2}$ - 오기철 ${ }^{3}$ - 김봉규 ${ }^{1}$

Received: 29 January 2018 / Accepted: 8 February 2018 / Published Online: 31 March 2018

(C) The Korean Society for Applied Biological Chemistry 2018

\begin{abstract}
This study was conducted to isolate the cellulolytic bacteria able to grow on LB- Carboxymethyl cellulose (CMC) agar trypan blue medium from the mixed forest and Larix leptolepis stands. Three bacterial strains with high activity against both CMC and xylan were isolated. Both API kit test and 16S rRNA gene sequence analysis revealed that the three different isolates belong to the gene Bacillus. Therefore, the isolates named as Bacillus sp. EFL1, Bacillus sp. EFL2, and Bacillus sp. EFP3. The optimum growth temperature of Bacillus sp. EFL1, EFL2, and EFP3 were $37^{\circ} \mathrm{C}$. The optimum temperature for CMCase and xylanase from Bacillus sp. EFL1 were $50{ }^{\circ} \mathrm{C}$. The optimum $\mathrm{pH}$ of Bacillus sp. EFL1 xylanase was $\mathrm{pH} 5.0$ but the optimum $\mathrm{pH}$ of CMCase from Bacillus sp. EFL1 was $\mathrm{pH}$ 6.0. The optimum temperature of CMCase and xylanase from Bacillus sp. EFL2 was $60{ }^{\circ} \mathrm{C}$, respectively. The optimum $\mathrm{pH}$ of CMCase of Bacillus sp. EFL2 was 5.0, whereas xylanase showed high activity at $\mathrm{pH} 3.0$ 9.0. The optimum temperature for CMCase and xylanase of
\end{abstract}

Kim Bong-Gyu $(\bowtie)$

E-mail: dkimbk@gntech.ac.kr

${ }^{1}$ Department of Forest Resources, Gyeongnam National University of Science and Technology, 33 Dongjin-ro, Jinju-si, Gyeongsangman-do, Jinju 52725, Republic of Korea

${ }^{2}$ Division of Special Purpose Tree, National Institute of Forest Science, Suwon 16631, Republic of Korea

${ }^{3}$ Nakdong River Basin Environmental Office, Changwon 51439, Republic of Korea

This is an Open Access article distributed under the terms of the Creative Commons Attribution Non-Commercial License (http://creativecommons. org/licenses/by-nc/3.0/) which permits unrestricted non-commercial use, distribution, and reproduction in any medium, provided the original work is properly cited.
Bacillus sp. EFP3 was $50^{\circ} \mathrm{C}$. The optimum $\mathrm{pH}$ for CMCase and xylanse was 5.0 and 4.0, respectively. CMCases from Bacillus sp. EFL1, EFL2, and EFP3 were thermally unstable. Although xylanase from Bacillus sp. EFL1 and EFP3 showed to be thermally unstable, xylanase from Bacillus sp. EFL2 showed to be thermally stable. Therefore, Bacillus sp. EFL2 has great potential for animal feed, biofuels, and food industry applications.

Keywords Bacillus sp. C Carboxymethyl cellulase · Lignocellulose - Xylanase

\section{서 론}

리그노셀룰로오스는 광합성에 의해 합성되는 지구상에서 가장 풍부한 유기물로 셀룰로오스, 헤미셀룰로오스, 리그닌 등으로 구 성되어 있다(Whitaker 1990; Kim 등, 2012). 피자식물의 경우 일반적으로 $42-50 \%$ 셀룰로오스, $25-30 \%$ 헤미셀룰로오스, 20 $25 \%$ 리그닌, $5-8 \%$ 의 기타 유기물로 구성되어 있다(Kumar 등, 2008). 셀룰로오스는 지구상에서 가장 풍부한 생체고분자물질로 $\beta$-D-glucose pyranose단위체로 구성된 동형다당류로 셀룰로오스 분해 효소인 endoglucanase (EC3.2.1.4), exoglucanase (EC3.2.1.91), $\beta$-glucosidase (EC3.2.1.21) 등의 상호협동작용에 의해 단당류인 D-glucose로 분해가 된다(Cai 등, 1999; Bayer 등, 2007; Kumar 등, 2008). 헤미셀룰로오스의 주성분은 자일란이며 셀룰로오스 다음으로 지구상에서 풍부한 생물고분자물질이다. 자일란은 활 엽수의 경우 식물세포벽의 $15-30 \%$, 침엽수의 경우 $4-10 \%$ 를 구 성하고 있다(Kulkarni 등, 1999; Singh 등, 2003). 자일란은 $\beta$ 1,4-D-endoxylanase (EC 3.2.1.8), $\beta$-xylosidase (EC 3.2.1.37)의 상호작용에 의해 분해된다(Kumar 등, 2008; Cantarel 등, 2014). 
산림은 다양한 생명체가 존재하며 이들의 상호작용에 의해 복잡한 생태계를 형성하고 있다. 식물을 제외한 나머지 생명체 들은 에너지를 직접 생산할 수 없기 때문에 식물이 만들어내는 유기물에 의존하여 살아가고 있다(Yang 등, 2014). 따라서 건전 한 생태환경을 위해서는 일차적으로 유기물을 분해하여 생태계 에 에너지원을 공급해주는 미생물들의 역할이 매우 중요하다 (Demain 등, 2005). 목질계바이오매스는 다양한 물질들과 복잡한 구조를 이루고 있기 때문에 생명체가 이용할 수 있는 에너지원인 단당류형태로의 전환을 위해서는 목재부후균 또는 박테리아와 같 은 다양한 미생물들의 역할이 필요하다. 대표적인 목재부후균은 Trichoderma속, Aspergillus속, Rhizopus속 등 (Murashima 등, 2002; Oh 등, 2003; Saito 등, 2003; Sohail 등, 2009)이 있고, 세균은 Bacillus속, Clostridium속, Streptomyces속 등이 목질계 바이오매스 분해와 관련된 다양한 효소를 생산하는 것으로 알 려져 있다(Robson과 Chambliss 1989; Mosolova 등, 1993; Lee 등, 2008; Kim 등, 2012; Lee 등, 2016). 기존에는 대부 분의 목질계바이오매스 분해는 목재부후균의 활동과 관련이 있 다고 알려졌지만, 메타게놈분석법의 발전으로 이전의 연구방법 으로는 알려져 있지 않은 다양한 종류의 미생물들이 여기에 관 여한다는 것이 알려졌다. 최근의 연구결과에 의하면 산림토양의 대표적인 세균은 Pseudomonas속, Bacillus속, Rhizobacter속, Arthrobacter속, Paenibacillus속 등 이다(Wilson 2011; Yang 등, 2014). 이와 같이 산림에는 목질바이오매스를 분해하여 먹고 사 는 다양한 종류의 미생물들이 존재하기 때문에 산업적으로 유 용한 미생물을 탐색하기 위한 중요한 보고이다( $\mathrm{Li}$ 등, 2009). 이 러한 지역에서 순수 분리한 우수한 미생물들은 펄프산업, 식품 산업, 바이오에탄올 생산 등과 같은 각종 산업에 적용 가능하 다. 특히, Bacillus속은 목질바이오매스를 분해하는데 필요한 다 양한 효소들을 생합성 할 뿐만 아니라 효모나 곰팡보다 상대적 으로 배양이 쉽고, 생장속도가 빠르고, 유전자 조작이 가능하기 때문에 식품산업, 펄프산업, 동물 사료산업 등과 같은 다양한 산업에 이용되고 있다(Lynd 등, 2002; Tjalsma 등, 2004; Khandeparker 등, 2011; Zang과 Zhang 2011).

본 연구에서는 활엽수림에서 침엽수림으로 생태천이가 일어 나고 있는 혼효림지대와 식재 후 약 60년이 지난 일본잎갈나무 림으로 부터 우수한 섬유소 분해 효과를 보이는 Bacillus sp. EFL1, Bacillus sp. EFL2, Bacillus sp. EFP3를 분리 - 동정 하 였다. 또한 이들 박테리아가 생산하는 Carboxymethyl cellulose (CMCase)와 xylanase의 생화학적 특성들을 조사하였다.

\section{재료 및 방법}

\section{당화 토양 박테리아 분리}

당화 가능한 토양 박테리아를 분리하기 위해 경상남도 산청군 금서면 수철리에 위치한 경남과학기술대학교 학술림내 고동재 부근에서 2016년 8월에 혼효림(잣나무-참나무)과 약 60년생의 낙엽송 동령림에서 각각 토양 샘플을 채집하였다. 혼효림의 상 층은 리기다소나무, 잣나무가 우점하는 가운데 상수리나무가 높 은 빈도로 출현하였다. 하층은 비목나무, 잣나무, 상수리나무, 생강나무 등이 자생하고 있었다. 낙엽송림은 상층은 낙엽송 하 층은 생강나무, 국수나무, 물푸레나무가 우점하고 있었다. 토양
샘플은 서로 다른 네 곳의 장소로부터 채취되었다. 토양 샘플 은 $70 \%$ 에탄올로 표면 살균한 원예용 모종삽으로 지표면에서 $10 \mathrm{~cm}$ 깊이로부터 약 $200 \mathrm{~g}$ 의 토양을 채취하였다. 토양샘플은 아이스박스에 담아 실험실로 옮겨졌고, 2-mm의 그물을 가진 체 를 이용하여 샘플 내 부유물 및 큰 입자를 제거한 후 나머지 토양을 후속 실험에 사용하였다.

토양미생물을 배양하기 위하여 멸균수 $9 \mathrm{~mL}$ 가 든 삼각플라 스크에 토양 샘플 $1 \mathrm{~g}$ 을 첨가하여 $200 \mathrm{rpm}, 30^{\circ} \mathrm{C}$ 인큐베이터에 서 30 분간 충분히 현탁 하였다. 샘플은 멸균수로 $10^{-1}-10^{-6}$ 까지 10 배씩 희석하여 LB-CMC agar plate (Tryptone $10 \mathrm{~g} / \mathrm{L}$, Yeast extract $5 \mathrm{~g} / \mathrm{L}, \mathrm{NaCl} 5 \mathrm{~g} / \mathrm{L}$, carboxy methyl cellulose (CMC) $5 \mathrm{~g} / \mathrm{L}$, Trypan blue $0.1 \mathrm{~g} / \mathrm{L}$, Agar $15 \mathrm{~g} / \mathrm{L}, \mathrm{pH}$ 5.7)에 $100 \mu \mathrm{L}$ 씩 도말 하여 48 시간 동안 $30^{\circ} \mathrm{C}$ 에서 배양하였다. 당화 박테리 아는 균총주위에 생성되는 halo의 유무에 따라 구분하였다. 당 화 효소를 생산하는 박테리아는 계대배양을 통하여 상대적으로 넓은 범위의 halo를 생성하는 박테리아들을 선정하여 순수 분 리하였다.

\section{당화 미생물의 동정}

순수 분리한 당화 토양박테리아의 동정은 VITEK 2 시스템과 $16 \mathrm{~S}$ rRNA 유전자분석법을 사용하였다. VITEK 분석은 API $50 \mathrm{CH}$ Kit (bioMetrieux, Vitek, France)을 이용하여 제조사로부 터 제공된 매뉴얼을 따랐다. $16 \mathrm{~S}$ rRNA 유전자로 토양미생물을 동정하기 위하여 $50 \mathrm{~mL}$ 의 $\mathrm{LB}$ 배지에 박테리아를 접종하여 $30{ }^{\circ} \mathrm{C}$ 에서 밤샘 배양한 후 Qiagen DNeasy kit (Hilden, Germany) 를 사용하여 제조사의 매뉴얼에 따라 박테리아의 게놈DNA를 분리하여 PCR반응에 사용하였다. $16 \mathrm{~S} \mathrm{rRNA}$ 유전자를 증폭은 Jang 등(2017)과 동일하게 수행하였다. PCR 산물은 pGEMTeasy vector (Promega, Madison, WI, USA)에 도입하여 염기서 열을 결정하였다. 염기서열은 National Center for Biotechnology Information (NCBI)에서 제공하는 BLASTN과 CLUSTAL W 프로그램으로 $16 \mathrm{~S}$ rRNA 유전자의 multiple sequence alignment 와 염기서열간의 유사도를 분석하였다. 계통도 작성은 Molecular Evolutionary Genetics Analysis 6.0 (MEGA 6.0) 프로그램에 내장되어 있는 neighbor-joining방법을 이용하였다(Tamura 등, 2013). 계통도의 신뢰도와 분지 패턴을 평가하기 위해 Bootstrap 분석 시 1,000 회 반복하여 생성된 데이터를 평가 기준으로 사 용하였다.

\section{효소활성 측정}

CMCase 또는 Xylanase의 측정은 환원당의 정량에 사용되는 DNS (3,5-dinitrosalicylic acid)법을 사용하였다(Miller 1959). CMCase 또는 Xylanase의 효소활성은 기질로 각각 $\mathrm{CMC}$ 와 xylan를 이용하여 $50{ }^{\circ} \mathrm{C}$ 에서 30 분간 반응 후 유리된 환원당의 양을 측정하여 평가하였다. 효소활성측정은 $1 \%(\mathrm{w} / \mathrm{v}) \mathrm{CMC}$ 또 는 xylan, $50 \mathrm{mM}$ sodium acetate buffer $(\mathrm{pH} 5.0)$, 조효소액이 0.5 unit가 되도록 첨가하고 나머지는 멸균수로 최종 볼륨을 1.0 $\mathrm{mL}$ 이 되도록 조절하여 실시하였다. 효소반응에서 생성된 환원 당의 확인은 동량의 $1 \% \mathrm{DNS}$ 용액을 첨가하여 잘 섞어 준 다 음 $100{ }^{\circ} \mathrm{C}$ 에서 5 분간 중탕하여 샘플을 발색 시킨 후 분광광도 계로 $540 \mathrm{~nm}$ 에서 측정값을 읽어 효소활성 계산에 이용하였다. 효소활성 1 unit은 분당 $1 \mu \mathrm{mol}$ 을 생성하는데 필요한 효소의 양 


\section{으로 정의하였다.}

CMCase 또는 Xylanase의 적정 $\mathrm{pH}$ 를 평가하기 위하여 $\mathrm{pH}$ 3.0-9.0 범위의 버퍼를 사용하였다. $\mathrm{pH} \quad 3.0-6.0$ 까지는 $50 \mathrm{mM}$ sodium acetate buffer, $\mathrm{pH} 7.0$ 과 8.0 은 $50 \mathrm{mM}$ sodium phosphate buffer, $\mathrm{pH}$ 8.0과 9.0은 $50 \mathrm{mM}$ Tris-Hcl buffer를 사용하였다. Xylanase 또는 CMCase의 효소활성에 영향을 미치는 최적 온 도의 결정은 $\mathrm{pH}$ 활성 실험에서 CMCase 또는 Xylanase에 대한 가장 높은 활성을 보인 $\mathrm{pH}$ buffer에 $1 \%(\mathrm{w} / \mathrm{v})$ xylan 또는 $\mathrm{CMC}$ 용액을 기질로 사용하여 $20-70{ }^{\circ} \mathrm{C}$ 까지 10 간격으로 각각 30 분간 반응을 실시한 후 $\mathrm{DNS}$ 법으로 효소의 활성을 측정하였 다. 효소의 온도안정성 평가는 효소들을 $40,50,70{ }^{\circ} \mathrm{C}$ 조건에 서 $0,15,30,45,60{ }^{\circ} \mathrm{C}, 75$ 분간 전 배양 후 $40{ }^{\circ} \mathrm{C}$ 에서 30 분 간 반응한 후 남아 있는 효소의 활성을 평가하였다.

\section{결과 및 고찰}

\section{리그노셀룰로오스 분해 박테리아 분리}

활엽수림지대와 낙엽송림지대의 지표면으로부터 약 $10 \mathrm{~cm}$ 깊이 에서 채취한 토양을 채취하여 trypan blue가 첨가된 LB-CMC agar plate에 골고루 도말하여 $30{ }^{\circ} \mathrm{C}$ 배양기에서 48 시간 배양한 후 미생물을 조사하였다. 배양된 미생물들 중에서 $\mathrm{CMC}$ 분해 가능한 미생물의 판별은 미생물의 colony주변에 형성하는 halo 의 존재 유무에 따라 식별하였다. 낙엽송림에서 채취한 토양샘 플로부터 미생물의 개체 수는 $2.1 \times 10^{6}$ colony-forming units $(\mathrm{CFU}) / 1 \mathrm{~g}$ 이었다. 이중에서 $\mathrm{CMC}$ 분해 능력을 가진 미생물은 $1 \mathrm{~g}$ 의 토양 당 $4.0 \times 10^{5} \mathrm{CFU}$ 로 전체 미생물 중에서 약 $20 \%$ 를 차지하였다. 혼효림에서 미생물의 개체수는 $1 \mathrm{~g}$ 의 토양당 약 3.5 $\times 10^{7} \mathrm{CFU}$ 였고, 이중 $\mathrm{CMC}$ 를 분해하는 박테리아는 토양 $1 \mathrm{~g}$ 당 $3.2 \times 10^{7} \mathrm{CFU}$ 로서 전체 박테리아의 약 $92 \%$ 를 차지하였다. 중국 의 장청의 산림지역 경우 $9.0 \times 10^{7} \mathrm{CFU}$ 의 미생물이 조사되었으 며, 이는 낙엽송림에 비해 약 43배, 혼효림에 비해 약 2.6배 더 많은 미생물의 밀도를 보였다(Yang 등, 2014). 하지만, 한국의 도심공원에서 조사되었던 배양 가능한 미생물의 수 $1.96 \times 10^{7}$ $\mathrm{CFU}$ 에 비해서 혼효림의 경우 약 1.8 배 정도 많은 미생물, 낙 엽송림은 약 9.3배 적은 미생물의 밀도를 보였다(Lee 등, 2016). 장청 산림지역의 리그노셀룰로오스 분해 미생물의 비율은 약 $37.2 \%$ 를 차지하고 있는 반면, 우리나라 도심공원지역의 리그노 셀룰로오스 분해 미생물의 비율은 약 $21 \%$ 였다. 이에 반해 낙 엽송림의 경우 약 $20 \%$, 혼효림의 경우 약 $92 \%$ 의 비율을 보였 다. 일반적으로 토양 미생물의 구성밀도는 토양생태계를 평가하 기 위한 중요한 요소이다. 토양의 특성이나, 지상부 식생의 구 조 및 수종의 종류 등은 토양의 미생물의 구성밀도에 결정적인 역할을 한다. 특히, 수분함량, $\mathrm{pH}$, 토양의 화학적 특성 등은 미 생물의 구성밀도에 중요한 영향을 미치는 인자로 알려져 있다 (Agnelli 등, 2004; Nikaus 등, 2006). 본 연구결과에서도 기존 연구결과들과 다른 미생물의 구성밀도 보여주는 가장 큰 요인 은 해당 지역에 자라고 있는 식생으로 인하여 유입되는 낙엽 · 낙지 등이 토양의 이화학적 특성에 영향을 미쳤기 때문인 것으 로 보인다.

\section{Vitek 및 $16 \mathrm{~S}$ rRNA를 이용한 미생물 동정}

혼효림과 낙엽송림 토양을 대상으로 실시한 LB-CMC trypan blue Agar plate 배양에서 상대적으로 넓은 halo를 보이는 20개 체의 미생물을 선발하여 계대배양을 통해 순수분리를 하였다. 각 개체들은 $\mathrm{LB}$ 액체배지에 $2 \mathrm{~mL}$ 에 접종하여 $30^{\circ} \mathrm{C}$ 에서 밤샘 배양한 후 다음날 아침 각 개체의 세포밀도를 $600 \mathrm{~nm}$ 에서 0.5 로 맞춘 후 $30{ }^{\circ} \mathrm{C}$ 에서 24 시간 배양하였다. 배양 후 원심분리로 상등액을 회수한 후 효소활성을 측정하였다. 그 중에서 높은 효 소활성을 보이는 3 개의 균주를 선발하였다.

균주를 동정하기 위하여 그람 양성 $\mathrm{API} 50 \mathrm{CHB}$ kit을 사용하 였다. 균주 $\mathrm{EFL1}$ 은 $\beta$-xylosidase, $\beta$-galactosidase, L-pyrrolydonylarylamidase, $\alpha$-galactosidase, $\beta$-glucosidase, $\beta$-mannosidase, $\alpha$ glucosidase 등의 효소활성을 가지는 반면 $\beta$-N-acetyl-glucosaminidase, $\alpha$-Mannosidase 등의 효소활성은 없었다. Kanamycin 과 oleandomycine에 대한 저항성이 없었다. 이와 같은 생화학적 특성에 근거하여 EFL1은 Bacillus subtilis/amyloliquenfaciens/ atrophaeus의 종(Species)일 확률이 $91 \%$ 였다(Table 1).

균주 $\mathrm{EFL} 2$ 는 $\beta$-xylosidase, $\beta$-galactosidase, $\alpha$-galactosidase, $\beta$-N-acetyl-glucosaminidase, $\alpha$-mannosidase, $\beta$-glucosidase, $\beta$ mannosidase 등의 효소활성을 가지는 반면 L-lysine-arylamidase, L-aspartate arylamidase, L-proline arylamidase, L-pyrrolydonylarylamidase, $\alpha$-glucosidase 등의 활성은 없었다. Kanamycin과 oleandomycine에 대한 저항성은 없었다. 이러한 생화학적 특성 에 근거하여 EFL2-1은 Bacillus pumilus의 종일 확률이 94\%였 다(Table 1).

균주 EFP3는 $\beta$-xylosidase, $\beta$-galactosidase, $\alpha$-galactosidase, $\beta$-N-acetyl-glucosamidase, $\beta$-glucosidase, $\beta$-mannosidase, $\alpha$ glucosidase 등의 효소활성을 가지는 반면, L-lysine-arylamidase, L-aspartate arylamidase, L-proline arylamidase, $\alpha$-mannosidase 등의 효소활성은 보이지 않았다. EFP3은 Kanamycin에 대한 저 항성을 가지고 있었다. 이러한 생화학적 특성에 근거하여 $\mathrm{EFP} 3$ 는 Bacillus subtilis/amyloliquenfaciens/atrophaeus 종(Species)일 확률이 $97 \%$ 였다(Table 1).

3 개의 균을 $16 \mathrm{~S} \mathrm{rRNA}$ 유전자 염기서열 분석으로 최종적으로 동정을 실시하였다. 각각의 염기서열은 $\mathrm{NCBI}$ 웹사이트에 탑재되 어 있는 BLAST의 blastn프로그램을 이용하여 $16 \mathrm{~S}$ ribosomal $\mathrm{RNA}$ 염기서열의 데이터베이스와 비교 분석하였다.

EFL1은 Bacillus thuringiensis (Bt18247), Bacillus toyonensis, Bacillus thuringiensis (ATCC 10792), Bacillus cereus (ATCC 14579 ) 등과 $99 \%$ 의 상동성, Bacillus manliponensis (BL4-6)와 $98 \%$ 의 상동성, Bacillus pseudomycoides와 $97 \%$ 의 상동성을 보 였다. Fig. 1에서 보는 바와 같이 유연관계분석에서 EFL1의 균 주는 Bacillus acidicola 105-2T (AF547209), Bacillus pallidus CW 7T (EU364818) 균주와 같은 계통에 속하였다. 이상의 결 과를 종합하면 EFL1은 Bacillus 종에 속하는 것을 알 수 있다. 따라서 본 균주는 Bacillus sp. EFL1로 명명하였다.

EFL2은 Bacillus stratosphericus (41KF2a), Bacillus safensis (NBRC 100820), Bacillus pumilus (NBRC 12092) 등과 99\%, Bacillus subtilis strain 168과 Bacillus amyloliquefaciens subsp. plantarum (FZB42)와 97\%의 상동성을 보였다. 유연관계 
Table 1 Biochemical properties of Bacillus sp. EFL1, EFL2, and EFP3

\begin{tabular}{|c|c|c|c|c|c|c|}
\hline \multirow{2}{*}{ Mnemonic } & \multirow{2}{*}{ Biochemical test (Substrate) } & \multirow{2}{*}{ Test type } & \multirow{2}{*}{ Wave length } & \multicolumn{3}{|c|}{ Details } \\
\hline & & & & EFL1 & EFL2 & EFP3 \\
\hline BXYL & BETA-XYLOSIDASE & Enzymatic & 430 & + & + & + \\
\hline LysA & L-Lysine-ARYLAMIDASE & Enzymatic & 430 & - & - & - \\
\hline AspA & L-Aspartate ARYLAMIDASE & Enzymatic & 660 & - & - & - \\
\hline LeuA & Leucine ARYLAMIDASE & Enzymatic & 660 & + & - & + \\
\hline PheA & Phenylalanine ARYLAMIDASE & Enzymatic & 660 & + & + & + \\
\hline ProA & L-Proline ARYLAMIDASE & Enzymatic & 660 & - & - & - \\
\hline BGAL & BETA-GALACTOSIDASE & Enzymatic & 430 & + & + & + \\
\hline PyrA & L-Pyrrolydonyl-ARYLAMIDASE & Enzymatic & 660 & + & - & + \\
\hline AGAL & ALPHA-GALACTOSIDASE & Enzymatic & 430 & + & + & + \\
\hline AlaA & Alanine ARYLAMIDASE & Enzymatic & 660 & + & - & + \\
\hline TyrA & Tyrosine ARYLAMIDASE & Enzymatic & 660 & + & + & + \\
\hline BNAG & BETA-N-ACETYL-GLUCOSAMINIDASE & Enzymatic & 430 & - & + & + \\
\hline APPA & Ala-Phe-Pro ARYLAMIDASE & Enzymatic & 660 & - & + & - \\
\hline CDEX & CYCLODEXTRINE & Acidification & 660 & - & - & - \\
\hline dGAL & D-GALACTOSE & Acidification & 660 & - & + & - \\
\hline GLYG & GLYCOGENE & Acidification & 660 & $(-)$ & - & $(+)$ \\
\hline INO & myo-INOSITOL & Acidification & 660 & + & - & + \\
\hline MdG & METHYL-A-D-GLUCOPYRANOSIDE & Acidification & 660 & + & $(-)$ & + \\
\hline ELLM & ELLMAN & Enzymatic & 430 & + & $(-)$ & + \\
\hline $\operatorname{MdX}$ & METHYL-D-XYLOSIDE & Acidification & 660 & - & - & - \\
\hline AMAN & ALPHA-MANNOSIDASE & Enzymatic & 430 & - & + & - \\
\hline MTE & MALTOTRIOSE & Acidification & 660 & + & - & + \\
\hline GlyA & Glycine ARYLAMIDASE & Enzymatic & 430 & + & $(+)$ & + \\
\hline dMAN & D-MANNITOL & Acidification & 660 & + & + & + \\
\hline dMNE & D-MANNOSE & Acidification & 660 & + & + & + \\
\hline $\mathrm{dMLZ}$ & D-MELEZITOSE & Acidification & 660 & - & - & - \\
\hline NAG & N-ACETYL-D-GLUCOSAMINE & Acidification & 660 & - & - & - \\
\hline PLE & PALATINOSE & Acidification & 660 & + & - & + \\
\hline IRHA & L-RHAMNOSE & Acidification & 660 & - & - & - \\
\hline BGLU & BETA-GLUCOSIDASE & Enzymatic & 430 & + & + & + \\
\hline BMAN & BETA-MANNOSIDASE & Enzymatic & 430 & + & + & + \\
\hline PHC & PHOSPHORYL CHOLINE & Enzymatic & 430 & - & - & - \\
\hline PVATE & PYRUVATE & Alkalinisation & 660 & - & + & + \\
\hline AGLU & ALPHA-GLUCOSIDASE & Enzymatic & 430 & + & - & + \\
\hline dTAG & D-TAGATOSE & Acidification & 660 & - & + & - \\
\hline dTRE & D-TREHALOSE & Acidification & 660 & + & + & + \\
\hline INU & INULIN & Acidification & 660 & + & - & + \\
\hline dGLU & D-GLUCOSE & Acidification & 660 & + & + & + \\
\hline dRIB & D-RIBOSE & Acidification & 660 & + & + & + \\
\hline PSCNa & PUTRESCINE assimilation & Assimilation & 660 & - & - & - \\
\hline $\mathrm{NaCl} 6,5 \%$ & Growth in $6,5 \% \mathrm{NaCl}$ & Inhibition & 660 & + & + & + \\
\hline KAN & KANAMYCIN RESISTANCE & Inhibition & 660 & + & - & $(+)$ \\
\hline OLD & OLEANDOMYCIN RESISTANCE & Inhibition & 660 & + & - & - \\
\hline $\mathrm{ESC}$ & ESCULIN hydrolyse & Precipitation & 660 & + & + & + \\
\hline TTZ & TETRAZOLIM RED & Precipitation & 660 & + & + & + \\
\hline POLYB_R & PLOMIXIN_B RESISTANCE & Inhibition & 660 & + & - & + \\
\hline
\end{tabular}

분석에서 Bacillus sp. EFL2는 Bacillus safensis FO-036bR와 Bacillus sp. MX47과 같은 계통에 속하였다. 따라서 본 균주는 Bacillus sp. EFL2로 명명하였다.

EFP3-1의 경우 Bacillus subtilis strain 168, Bacillus subtilis strain IAM 12118, Bacillus amyloliquefaciens subsp. plantarum (FZB42) 등과 99\%, Bacillus atrophaeus (NBRC 15539)와 Bacillus licheniformis (ATCC 14580)과 98\%의 상동성을 보였다. 유연관계분석 결과 $\mathrm{EFP} 3$ 의 균주는 Bacillus methylotrophicus 


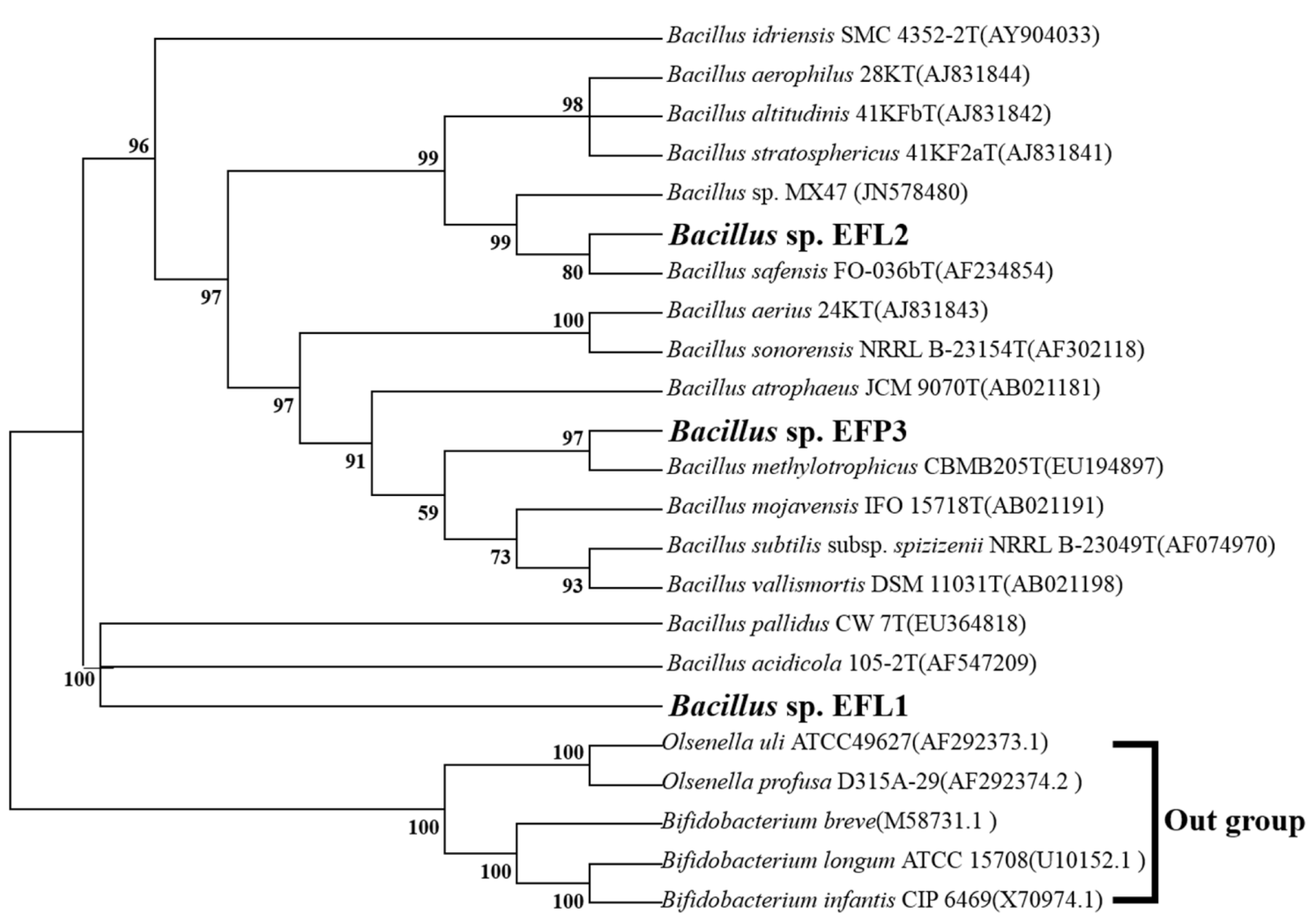

Fig. 1 16S rRNA gene sequence-based phylogenetic tree of Bacillus sp. EFL1, EFL2, and ELP3 with related bacteria 16S rRNA genes. Kimura twoparameter model was used to determine the distance matrix. The bootstrap values were obtained using 1000 replicates regenerated with random method

$\mathrm{CBMB} 205 \mathrm{~T}$ 균주와 같은 계통에 속하였다. 이상의 결과에 의하 면 EFP3은 Bacillus속에 속하였으며, Bacillus sp. EFP3로 명명 하였다.

\section{Bacillus sp. EFL1, EFL2, EFP3의 생장특성}

Bacillus sp. EFL1, EFL2, EFP3의 적정생장온도를 알아보기 위 하여 $20,30,37,45^{\circ} \mathrm{C}$ 에서 정치 배양을 실시하였다. 분리된 균주 모두 $37^{\circ} \mathrm{C}$ 에서 가장 양호한 생장을 보였고 다음으로 $30{ }^{\circ} \mathrm{C}$ 였다. $20^{\circ} \mathrm{C}$ 에서는 $37{ }^{\circ} \mathrm{C}$ 에 비해 약 $32 \%$ 의 생장량을 보였 고, $45^{\circ} \mathrm{C}$ 에서는 $37^{\circ} \mathrm{C}$ 에 비해 약 $65 \%$ 정도의 생장을 보였다. 이상의 결과로 보아 본 연구에서 분리한 미생물들은 모두 중온 성 미생물에 속하였다.

각 미생물들의 생장패턴과 효소활성의 변화를 관찰하였다. 각 미생물들은 $\mathrm{LB}$ 배지에 $\mathrm{OD} 600 \mathrm{~nm}$ 에서 0.05 로 접종하여 $37^{\circ} \mathrm{C}$ 에서 배양을 실시한 후 $0,2,4,8,12,24,36,48$ 시간에 샘플 을 회수하여 미생물의 생장 및 CMCase 및 xylanase의 효소활 성을 측정하였다. Bacillus sp. EFL1은 배양 후 약 2시간부터 생장이 조금씩 증가하기 시작하여 24시간에 생장이 최고에 도 달한 후 서서히 생장이 줄어 들었다. Xylanase활성은 배양 4시 간부터 급속하게 증가하여 12 시간에 최고에 도달하였으며, 점 차 활성이 줄어드는 양상을 보였다. CMCase의 경우 xylanase 와 마찬가지로 배양 후 4시간부터 활성이 증가하여 배양 후 24 시간에 최대에 도달한 후 점차 감소하는 경향을 보였다(Fig. 2A).

Bacillus sp. EFL2은배양 후 24시간에 최대 생장에 도달한
후 서서히 생장이 줄어드는 양상을 보였다. Xylanase는 배양한 후 12시간 까지 점차적으로 효소활성이 증가되는 양상보이다가 그 이후 효소활성이 점차 줄어드는 양상을 보였다. CMCase의 경우 배양 후 2시간부터 효소활성이 증가하기 시작하여 24시간 에 최대활성을 보였다(Fig. 2B).

Bacillus sp. EFP3은 배양 후 12시간에 최대생장에 도달하였 다. Xylanase활성은 배양 4시간 후부터 증가하기 시작하여 배 양 후 8시간 후에 최대 활성을 보인 후 조금씩 줄어드는 양상 을 보였다. $\mathrm{CMCase}$ 는 배양 후 24시간에 최대활성을 보였고 그 후 활성이 점차 감소하였다(Fig. 2C). 이상의 결과에서 3개의 Bacillus sp.들의 생장량이 배양 후 24시간에 최대에 도달하였고 그 후 점차 줄어드는 양상을 보였다. 이러한 결과는 배양 후 24 시간 정도 지나면 미생물의 배양을 위해 사용된 배지 내에 공 급된 영양원이 고갈되어 생장 중에 있는 미생물들이 더 이상 사용할 영양분이 남아 있지 않기 때문에 미생물의 생장이 오히 려 줄어드는 양상을 보이는 것으로 보인다. 또한 위의 결과에 서 알 수 있듯이 CMCase와 xylanase의 효소활성도 미생물의 생장량과 비슷한 양상을 보였다. 이러한 이유도 배지 내에 공 급된 탄소원의 고갈로 인하여 CMCase와 xylanase와 같은 효소 합성의 필요성이 줄었을 뿐만 아니라 효소합성에 필요한 에너 지 및 아미노산 등의 공급 제한에 의해 야기되는 것으로 보인다.

CMCase와 Xylanase의 최적 온도 및 $\mathbf{p H}$

Bacillus sp. EFL1, EFL2, EFP3가 생산하는 CMCase와 xylanase 의 활성에 영향을 미치는 $\mathrm{pH}$ 및 온도에 대한 영항을 조사하였 

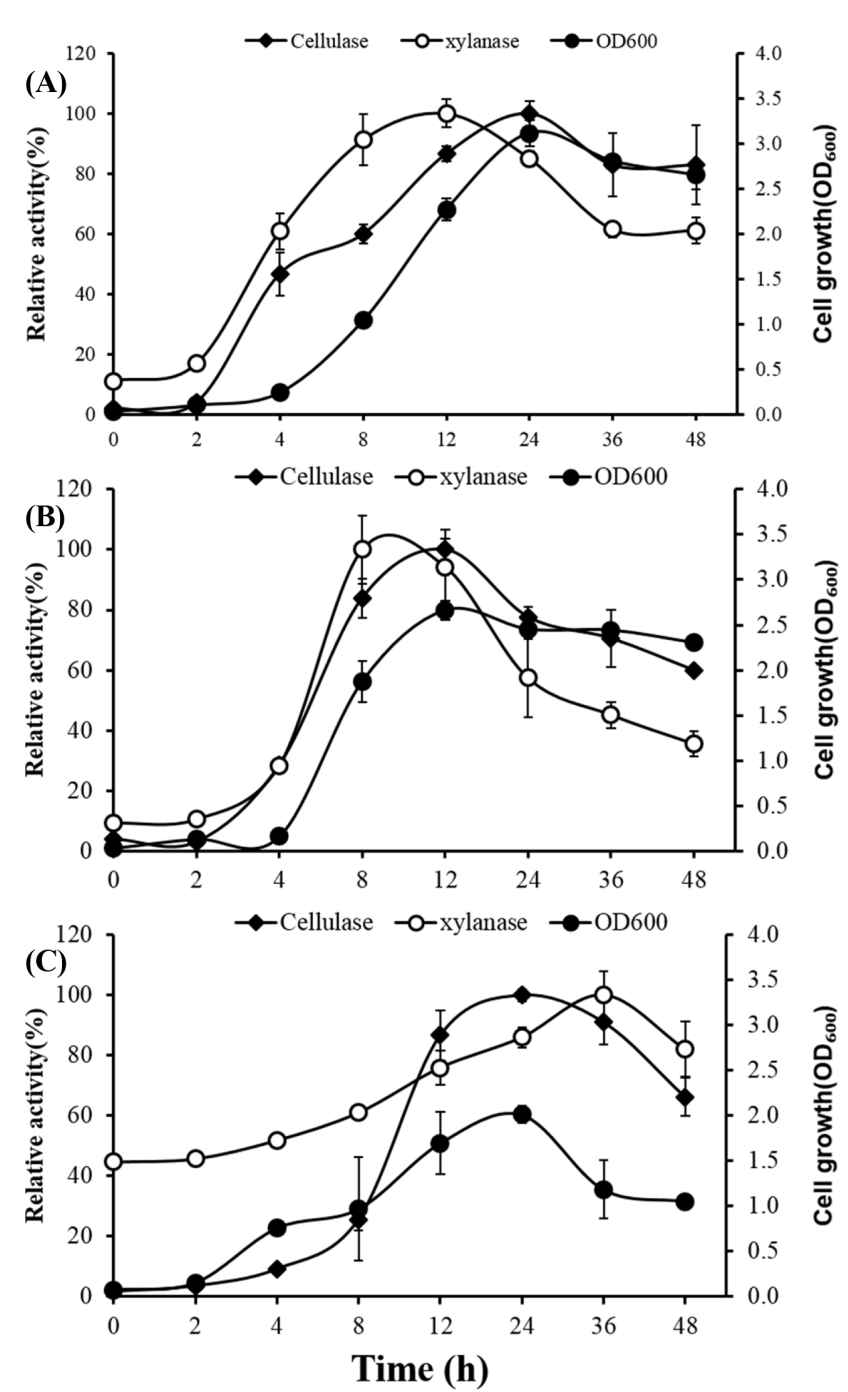

Fig. 2 Bacterial growth of Bacillus sp. EFL1, EFL2, and EFP3 and the enzymatic activities of xylanase and CMCase during the growth. Bacillus sp. EFL1, EFL2, and EFP3 were cultured at $37^{\circ} \mathrm{C}$ with 200rpm shaking. The enzymatic activities were determined in $50 \mathrm{mM}$ sodium acetate buffer supplemented with $1 \%(\mathrm{w} / \mathrm{v}) \mathrm{CMC}$ and xylan at $50{ }^{\circ} \mathrm{C}$. All results are presented by mean $\pm S D(n=3)$

다. 각 균주들이 생산하는 CMCase와 xylanase의 활성에 영향 을 미치는 적정 $\mathrm{pH}$ 를 조사하기 위하여 $50{ }^{\circ} \mathrm{C}$ 의 동일조건에서 $\mathrm{pH}$ 3.0-9.0의 범위에서 효소활성을 측정하였다.

Bacillus sp. EFL1이 생산하는 CMCase는 $\mathrm{pH}$ 5.0-7.0까지 가장 높은 효소활성을 보였으며 $\mathrm{pH} 9.0$ 에서는 약 $60 \%$ 정도의 효소활성을 보였다(Fig. 3A). Xylanase의 경우 $\mathrm{pH} 6.0$ 에서 가장 높을 활성을 보였지만, $\mathrm{pH} 4.0$ 과 5.0 의 약산성과 $\mathrm{pH} 7.0$ 의 중 성, $\mathrm{pH} 8.0$ 의 약 알칼리성에도 약 $80 \%$ 이상의 활성을 보였다 (Fig. $3 \mathrm{~A}) . \mathrm{pH} 5.0$ 의 버퍼의 공통적인 조건에 $20-70{ }^{\circ} \mathrm{C}$ 사이의 범위에서 Bacillus sp. EFL1 CMCase와 xylanase의 활성에 미 치는 온도의 영향을 조사하였다. $\mathrm{CMCase}$ 와 xylanase는 $50{ }^{\circ} \mathrm{C}$ 의 온도에서 가장 높은 활성을 보였다. $\mathrm{CMCase}$ 는 $60{ }^{\circ} \mathrm{C}$ 이상에서 도 최대 활성의 약 $67 \%$ 유지하였다. Xylanase의 활성은 $60{ }^{\circ} \mathrm{C}$
과 $70{ }^{\circ} \mathrm{C}$ 에서도 최대활성의 $80 \%$ 이상을 유지한 반면 낮은 온 도에서는 효소활성이 감소하는 경향을 보였다. 이는 기존에 보 고되었던 Bacillus속 유래 목질계 분해 효소들과 유사한 경향을 보이는 것을 알 수 있었다(Fig. 3B).

Bacillus sp. EFL2이 생산하는 CMCase의 경우 $\mathrm{pH} 5.0$ 에서 가장 높은 효소활성을 보였다. $\mathrm{pH} 3.0,4.0,6.0$ 에서도 약 $80 \%$ 이상의 활성을 유지하였다. 하지만, $\mathrm{pH} 9.0$ 에서는 효소활성을 거의 잃어버렸다. Xylanase의 경우 $\mathrm{pH} 8.0$ 에서 가장 높을 활 성을 보였지만, $\mathrm{pH}$ 4.07.0까지 범위에서도 비교적 $80 \%$ 이상의 높은 효소활성이 유지되는 것을 보였다(Fig. 3C). Bacillus sp. $\mathrm{EFL} 2$ 이 생산하는 $\mathrm{CMCase}$ 와 xylanase는 $60{ }^{\circ} \mathrm{C}$ 의 온도에서 최 대활성을 보였지만, $70{ }^{\circ} \mathrm{C}$ 에서도 최대활성의 $90 \%$ 를 유지하였다. 이는 기존에 보고되었던 Bacillus속 유래 목질계 분해 효소들과 비교해서 상당히 높은 온도에서도 효소활성을 유지하는 것을 알 수 있다(Fig. 3D). 이상의 결과를 종합해 보면 Bacillus sp. $\mathrm{EFL} 2$ 의 CMCase의 경우 산성과 중성에서 가장 높은 효소활성 을 보였고, xylanase의 경우 넓은 범위의 $\mathrm{pH}$ 에서 높은 효소활 성을 가지는 결과를 보였다. 이러한 결과는 Bacillus sp. EFL2 가 생산하는 xylanase의 경우 넓은 범위의 산업적 응용가능성 을 시사한다. 향후 Bacillus sp. EFL2를 이용한 미생물 토양개 량제의 가능성 여부 및 xylanase 유전자의 클로닝과 생화학적 특성 규명 등을 통해 제지산업, 식품산업 등의 다양한 산업적 환경 등의 이용가능성을 알아보기 위한 연구가 진행되어야 할 것으로 보인다.

Bacillus sp. EFP3이 생산하는 CMCase의 경우 $\mathrm{pH}$ 5.0에서 가장 높은 효소활성을 보인 반면, $\mathrm{pH} 3.0$ 에서 가장 낮은 효소 활성을 보였다. $\mathrm{pH}$ 6.0부터 조금씩 효소활성이 감소되어 $\mathrm{pH}$ 9.0 에서는 $\mathrm{pH} 5.0$ 과 비교해서 약 $60 \%$ 의 효소활성을 보였다. Xylanase의 경우 $\mathrm{pH}$ 4.0에서 가장 높은 활성을 보였고, $\mathrm{pH}$ 가 증가함에 따라 효소활성이 점차 감소하여 $\mathrm{pH} 9.0$ 에서는 $\mathrm{pH} 4.0$ 과 비교해서 약 $60 \%$ 정도의 활성을 보였다. 하지만, $\mathrm{pH} 8.0$ 까지는 약 $90 \%$ 정도의 효소활성을 보였다(Fig. 3E). Bacillus sp. EFL3이 생산하는 CMCase는 50 xylanase는 $60{ }^{\circ} \mathrm{C}$ 의 온도 에서 최대활성을 보였지만, $70{ }^{\circ} \mathrm{C}$ 에서도 최대활성의 $90 \%$ 이상 을 유지 하였다(Fig. 3F).

\section{CMCase와 Xylanase의 온도안정성}

Bacillus sp. EFL1, EFL2, EFP3가 생산하는 CMCase와 xylanase 의 온도안정성을 조사하였다. 각 효소들의 온도안정성에 대한 평가는 기질 없이 $40,50,70^{\circ} \mathrm{C}$ 에서 각각의 온도에서 15 분 간 격으로 75 분까지 배양한 후 남아 있는 효소의 활성을 평가하였다.

Bacillus sp. EFL1이 생산하는 CMCase의 경우 15 분 배양 후부터 활성이 급격하게 감소하여 배양 후 30 분에는 테스트한 모든 온도에서 $50 \%$ 이상 감소하는 경항을 보였지만, 그 이후 배양시간을 증가시켜도 활성이 거의 동일하게 유지되었다(Fig. 4A). Xylanase의 경우 $40{ }^{\circ} \mathrm{C}$ 를 제외한 대부분의 온도에서 15 분 배양 후부터 효소활성이 급격하게 감소하였고, 배양 75 분 후에 는 최대활성이 약 $20 \%$ 정도를 유지하고 있었다(Fig. 4B). 이상 의 결과를 종합해보면 Bacillus sp. EFL1이 생산하는 CMCase 와 Xylanase 의 경우 효소의 온도안정성이 굉장히 낮은 것을 알 수 있다.

Bacillus sp. EFL2가 생산하는 CMCase의 경우 테스트한 모 

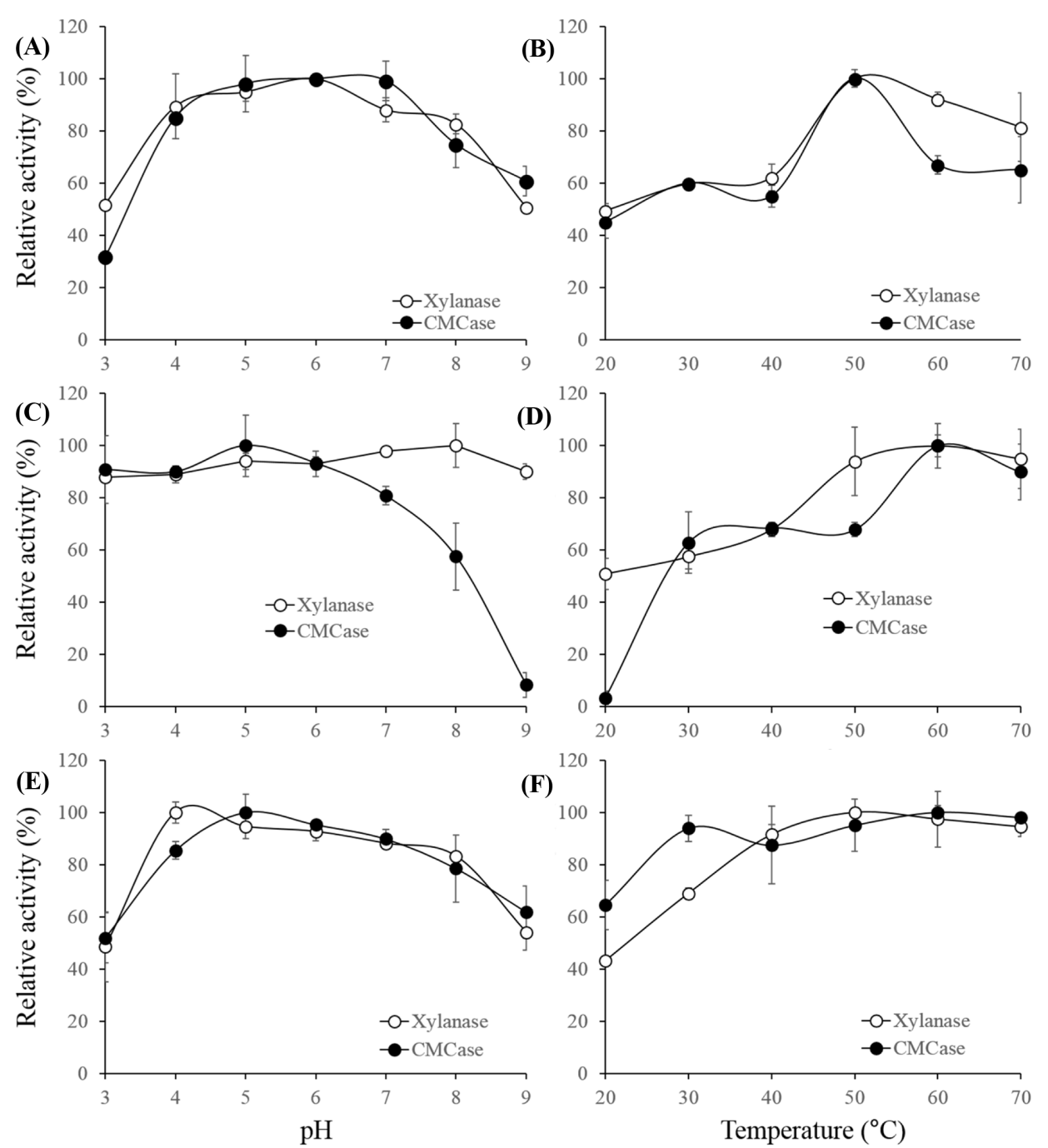

Fig. 3 Effect of $\mathrm{pH}(\mathrm{A}, \mathrm{C}$, and $\mathrm{E})$ and temperature (B, D, and F) on the activities of CMCase and xylanase obtained from Bacillus sp. EFL1 (A and B), EFL2 (C and D), EFP3 (E and F). The effect of $\mathrm{pH}$ and temperature were assessed with 50mM sodium acetate buffer and containing $1 \%(\mathrm{w} / \mathrm{v}) \mathrm{CMC}$ and birchwood xylan, respectively. All data are represented as mean \pm SD $(n=3)$

든 온도에서 15 분간 배양 후 일정한 패턴으로 효소의 활성이 감소되는 경향을 보였고, 30 분간 배양 후 테스트한 모든 온도 에서 약 $50 \%$ 정도의 활성이 남아 있었다. 그 후 효소의 배양 시간을 증가시켜도 더 이상 효소의 활성에는 영향을 미치지 않 는 경향을 보였다. 75 분간 배양 후 테스트한 모든 온도에서 약 $40 \%$ 정도의 효소활성이 남아 있었다(Fig. 4C). Xylanase의 경 우 $40,50,70^{\circ} \mathrm{C}$ 의 온도에서 15 분간 배양하였을 때 약 $90 \%$ 이상의 활성을 유지하였지만, $40{ }^{\circ} \mathrm{C}$ 에서 30 분간 배양 한 후 약 $65 \%$ 까지 효소활성이 줄었다. 하지만, $50{ }^{\circ} \mathrm{C}$ 의 경우 효소의 배 양시간을 증가시켜도 효소의 활성에는 거의 변화가 없었으며, 75 분간 배양한 후에도 약 $90 \%$ 정도의 효소활성이 남아 있는 것을 보였다. $70^{\circ} \mathrm{C}$ 의 경우도 비교적 효소의 활성이 안정적으로 유지되는 경향을 보였고 75 분간 배양한 후 남아 있는 효소의 활성이 약 $80 \%$ 이상으로 온도안정성 상당히 높은 것을 알 수 있다(Fig. 4D). 향후 Bacillus sp. EFL2의 xylanase를 코딩 하 는 유전자 분리 및 재조합 단백질 생산을 통한 효소의 생화학
적 연구 및 산업적 적용방법에 대한 연구가 수행되어야 할 것 으로 보인다.

Bacillus sp. EFP3가 생산하는 CMCase의 경우 $40{ }^{\circ} \mathrm{C}$ 에서는 15 분 배양 후부터 효소의 활성이 감소하기 시작하여 30 분 배양 후에는 초기 효소활성의 약 $50 \%$ 까지 감소하는 경향을 보였다. 하지만 그 이후 배양시간을 증가시켜도 효소의 활성은 계속 비 슷하게 유지되었다(Fig. $4 \mathrm{E}) .50,70{ }^{\circ} \mathrm{C}$ 의 경우 15 분 배양 후 대부분의 효소활성을 잃어버리는 결과를 보였다. Xylanase도 $\mathrm{CMCase}$ 와 마찬가지로 $40{ }^{\circ} \mathrm{C}$ 에서만 75 분간 배양하여도 약 $50 \%$ 정도의 잔존 활성을 보였지만, 나머지의 온도에서는 30 분간 배 양 후 효소의 활성의 거의 사라지는 경향을 보였다((Fig. 4F).

\section{초 록}

본 연구는 경상남도 산청군 소재 경남과학기술대학교 학술림에 

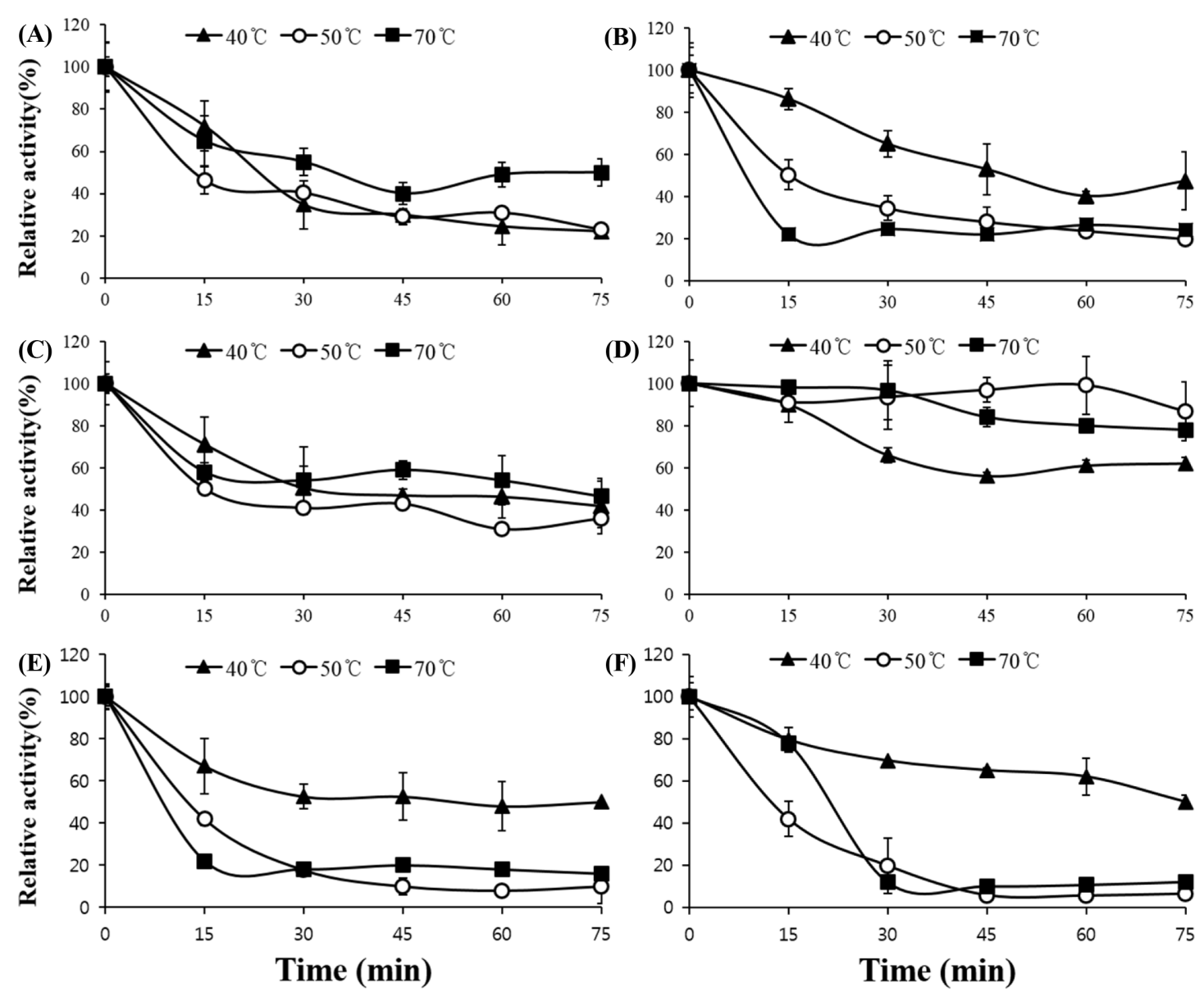

Fig. 4 Thermal stability of CMCase (A, C, and E) and xylanase (B, D, and F) from Bacillus sp. EFL1 (A and B), EFL2 (C and D), and EFP3 (E and F). The thermal stabilities of CMCase and xylanase were evaluated in $50 \mathrm{mM}$ sodium acetate buffer containing $1 \%$ (w/v) CMC and birchwood xylan at 40 , 50 , and $70^{\circ} \mathrm{C}$. All results are presented by mean $\pm \operatorname{SD}(n=3)$

서 채취한 토양으로부터 CMCase와 xylanase를 생산하는 3개의 Bacillus 종을 분리하였다. API kit 분석과 $16 \mathrm{~S}$ rRNA 유전자 염 기서열 분석을 통해 3 개의 균 모두 Bacillus종에 속하였으며, Bacillus sp. EFL1, EFL2, EFP3로 명명하였다. Bacillus sp. $\mathrm{EFL} 1, \mathrm{EFL} 2, \mathrm{EFP} 3$ 의 최적 생장온도는 $37^{\circ} \mathrm{C}$ 였으며, $\mathrm{CMCase}$ 와 xylanase의 활성은 배양 후 12 시간에 최고에 달하였다. Bacillus sp. EFL1의 CMCase 효소활성의 최적온도는 $50^{\circ} \mathrm{C}$, $\mathrm{pH}$ 는 5.0 이었고, xylanase 효소활성의 최적온도는 $50^{\circ} \mathrm{C}, \mathrm{pH}$ 6.0 이었다. Bacillus sp. EFL2의 CMCase활성의 최적온도는 $60{ }^{\circ} \mathrm{C}, \mathrm{pH}$ 는 5.0 이었고, xylanase 효소활성의 최적온도는 $60^{\circ} \mathrm{C}$ 였고, $\mathrm{pH}$ 3.0-9.0까지 비교적 높은 활성을 보였다. Bacillus sp. $\mathrm{EFP3}$ 의 $\mathrm{CMCase}$ 의 최적온도는 $50^{\circ} \mathrm{C}, \mathrm{pH}$ 는 5.0 이었고, xylanase의 최적온도는 $50^{\circ} \mathrm{C}, \mathrm{pH} 4.0^{\circ}$ 이었다. Bacillus sp. $\mathrm{EFL} 1, \mathrm{EFL} 2, \mathrm{EFP} 3$ 의 $\mathrm{CMCase}$ 는 모두 온도안정성이 낮았다. 또한 Bacillus sp. EFL1과 EFP3의 xylanase 역시 온도안정성이 낮았지만, Bacillus sp. EFL2의 xylanase는 온도안정성이 높았다.

Keywords 리그노세룰로오스 - 바실러스 - 자일라나아제·카르 복시메틸셀룰라아제
감사의 글 이 논문은 경남과학기술대학교 2016년도 대학회계 연구비에 의 하여 연구되었음.

\section{References}

Agnelli A, Ascher J, Corti G, Ceccherini MT, Nanniieri P, Pietramellra G (2004) Distribution of microbial communities in a forest soil profile investigated by microbial biomass, soil respiration and DGGE of total and extracellular DNA. Soil Biol Biochem 36: 859-868

Bayer EA, Lamed R, Himmel ME (2007) The potential of cellulases and cellulosomes for cellulosic waste management. Current opinion in Biotechnology 18(3): 237-245

Cai YJ, Chapman SJ, Buswell JA, Chang ST (1999) Production and distribution of endoglucanase, cellobiohydrolase, and beta-glucosidase components of the cellulolytic system of Volvariella volvacea, the edible straw mushroom. Appl Environ Microbiol 65: 553-559

Cantarel BL, Coutinho PM, Rancurel C, Bernard T, Lombard V, Henrissat B (2014) The carbohydrate-active enzymes database (CAZy) in 2013. Nucleic Acids Res 42: D490-495

Jang MY, Park HR, Lee CG, Choo GC, Cho HS, Park SB, Oh KC, Kim BG (2017) Isolation and biochemical characterization of acid tolerance xylanase producing Bacteria, Bacillus sp. GJY from city park soil. J 
Appl Biol Chem 60(1): 79-86

Khandeparker R, Verma P, Deobagkar D (2011) A novel halotolerant xylanase from marine isolate Bacillus subtilis cho40: gene cloning and sequencing. N Biotechnol 28: 814-821

Kim YK, Lee SC, Cho YY, Oh HJ (2012) Isolation cellulolytic Bacillus subtilis strains from agricultural environments. ISRN Microbiol Article ID 650563: 9

Kulkarni N, Shendye A, Rao M (1999) Molecular and biotechnological aspects of xylanases. FEMS Microbiology Reviews 1999; 23: 411-456

Kumar R, Singh S, Singh OV (2008) Bioconversion of lignocellulosic biomass: biochemical and molecular perspectives. $J$ Ind Microbiol Bioechnol 35: 377-391

Lee CK, Jang MY, Park HR, Choo GC, Cho HS, Park SB, Oh KC, An JB, Kim BG (2016) Cloning and characterization of xylanase in cellulolytic Bacillus sp. strain JMY1 isolated from forest soil. App Biol Chem 59(3): $415-423$

Lee YJ, Kim BK, Lee BH, Jo KI, Lee NK, Chung CH, Lee JW (2008) Purification and characterization of cellulase produced by Bacillus amyoliquefaciens DL-3 utilizing rice hull. Bioresource technology 99(2): 378-386

Li XH, Yang HJ, Roy B, Wang D, Yue WF, Jiang LJ, Miao YG (2009) The most stirring technology in future: Cellulase enzyme and biomass utilization. African Journal of Biotechnology 8(11)

Lynd LR, Weimer PJ, Van Zyl WH, Pretorius IS (2002) Microbial cellulose utilization: fundamentals and biotechnology. Microbiology and molecular biology reviews 66(3): 506-577

Miller GL (1959) Use of dinitrosalicylic acid reagent for determination of reducing sugar, Analytical Chemistry, 31(3): 426-428

Mosolova TP, Kalyuzhnyi SV, Varfolomeyev SD, Velikodvorskaya GA (1993) Purification and properties of Clostridium thermocellum endoglucanase 5 produced in Escherichia coli. Applied biochemistry and biotechnology 42(1): 9-18

Murashima K, Nishimura T, Nakamura Y, Koga J, Moriya T, Sumida N, Kono T (2002) Purification and characterization of new endo-1, 4- $\beta$-Dglucanases from Rhizopus oryzae. Enzyme and Microbial Technology 30(3): 319-326
Nikaus PA, Wardle DA, Tate KR (2006) Effects of plant species diversity and composion on nitrogen cycling and the trace gas balance of soils, Plant Soil 282: 83-98

Oh SH, Kim MS, So S, Suj HJ (2003) Studies on the Production of cellulase by Trichoderma sp. SO-571 and the Enzyme Treatment for Cellulosic Fabrics. J. Microbiol. Biotechnol 31(3): 42-45

Robson LM, Chambliss GH (1989) Cellulases of bacterial origin. Enzyme and Microbial Technology, 11(10): 626-644

Saito K, Kawamura Y, Oda Y (2003) Role of the pectinolytic enzyme in the lactic acid fermentation of potato pulp by Rhizopus oryzae. Journal of industrial microbiology \& biotechnology 30(7): 440-444

Singh S, Madlala AM, Prior BA (2003) Thermomyces lanuginosus: properties of strains and their hemicellulases. FEMS Microbiology Reviews 2003; 27: $3-16$

Sohail M, Siddiqi R, Ahmad A, Khan SA (2009) Cellulase production from Aspergillus niger MS82: effect of temperature and $\mathrm{pH}$. New Biotechnol 25(6): 437-41

Tamura K, Stecher G, Peterson D, Filipski A, Kumar S (2013) MEGA6: Molecular Evolutionary Genetics Analysis version 6.0. Mol Biol Evol 30: $2725-2729$

Tjalsma H, Antelmann H, Jongbloed JD, Braun PG, Darmon E, Dorenbos R, Kuipers OP (2004) Proteomics of protein secretion by Bacillus subtilis: separating the "secrets" of the secretion. Microbiology and Molecular Biology Reviews 68(2): 207-233

Whitaker JR (1990) Cellulase production and application. Food Biotechnol 4: 669-697

Wilson DB (2011) Microbial diversity of cellulose hydrolysis. Current opinion in microbiology 14(3): 259-263

Yang JK, Zhang JJ, Yu HY, Cheng JW, Miao LH (2014) Community composition and cellulase activity of cellulolytic bacteria from forest soils planted broad-leaved deciduous and evergreen trees. Appl Microbiol Biotechnol 98: 1449-1458

Zang XZ, Zhang YHP (2011) Simple, fast and high-efficiency transformation system for directed evolution of cellulase in Bacillus subtilis. Microbial Biotechnology 4: 98-105 